\title{
BABI : TERNAK KESAYANGAN ORANG MENTAWAI
}

\author{
Syaiful Kasman \\ Peneliti dari Yayasan Karekat Padang
}

\begin{abstract}
Pig has always been an important dishes are always available in religious ceremony in Mentawai Ethnic. Starting from marriage, death, an inauguration of the new house (uma), birth of a child ceremony. Virtually every traditional ceremony (Punen) there is always a pig as consumption of religious ceremony
\end{abstract}

\section{Keywords: Pig, Mentawai Ethnic, Uma, Religious Ceremnony}

\section{PENDAHULUAN}

$\mathrm{B}$ agi orang mentawai, babi merupakan hata milik terpenting (Schefold, $1991 ; 64)$. Begitu juga bagi orang sarereiket, ${ }^{\prime}$ bagi mereka babi merupakan salah satu hewan ternak yang terpenting. Babi merupakan hewan ternak yang selalu diperlukan dalam setiap punen ${ }^{2}$ yang dilaksanakan oleh masyarakat mentawai, khususnya orang-orang "sarereiket".

Bagi masyarakat sarereiket babi merupakan makanan yang sangat penting dalam keidupan mereka, khususnya dalam pesta adat (punen). Hal ini berbeda dengan pandangan para pemburu babi di daerah pinggiran kota padang. Pemburu di pinggiran kota Padang memandang babi sebagai mainan untuk diburu, hasil babi buruan bukan untuk dimakan atau di konsumsi (Kasman, 2014; 2).

Babi selalu menjadi hidangan penting yang selalu tersedia dalam punen. Mulai dari punen pernikahan, kematian, peresmian uma baru, kelahiran anak, dan lain sebagainya. Bisa dikatakan setiap upacara adat (Punen) selalu ada babi sebagai hidangan makannya (konsumsi dalam punen).

1 Sebutan bagi masyarakat mentawai yang tinggal di sepanjang daerah aliran sungai Rereiket (Siberut). Secara adsminitrasi pemerintahan orang sarereiket masuk dalam dua desa, yakni desa Matotonan dan desa Madobag. Jadi, penduduk (orang mentawai) Desa Madobag dan Desa Matotonan menyebut diri mereka orang sarereiket.

2 Punen artinya dalam bahasa Indonesia adalah pesta.Punen di sini diartikan sebagai suatu upacara adat
Dalam persoalan pernikahan, babi bukan hanya untuk konsumsi pesta. Namun babi juga digunakan sebagai pembayaran mahar atau maskawin. Pembayaran mahar atau maskawin ini dilakukan oleh pihak pegantin pria kepada pihak pengantin wanita. Dalam hal ini keluarga pengantin wanita yang akan menjemput mas kawin tersebut di kediamannya pengantin pria. Dalam mayarakat sarereiket proses pengambilan mas kawin ini di sebut dengan istilah "pasialak toga."

Selain itu untuk pembayaran denda adat (tulou) bisa juga menggunakan babi. Kemudian babi juga bisa dijual kepada penampung yang ada di kawasan Muara Siberut. Hal ini juga menambah arti penting hewan ternak babi.

Pentingnya babi di dalam maysarakat sarereiket membuat hampir setiap keluarga inti mempunyai peternakan babi sendiri. Secara mandiri satu keluarga inti mngelola peternakan babinya sendiri. Meskipun dikelola sendiri secara mandiri jika babi tersebut disembelih maka daging babi tersebut akan tetap dibagi-bagikan dengan anggota satu suku lainnya (satu uma).

Menurut Suparlan (2004; 4) kebudayaan merupakan pedoman bagi kehidupan manusia yang secara bersama dimiliki oleh para warga sebuah masyarakat. Dengan kata lain kebudayaan adalah sebuah pedoman menyeluruh bagi kehidupan sebuah masyarakat dan para warganya. Kebudayaan dilihat sebagai konsep-konsep, teori-teori, dan metode yang diyakini kebenarannya oleh warga masyarakat yang jadi pemiliknya. Kebudayaan dengan demikian merupakan sistem-sistem acuan yang berada pada berbagai tingkat pengetahuan dan kesadaran, sistem acuan 
ini yang digunakan oleh manusia untuk menghadapi ligkungannya.

Masyarakat sarereiket memiliki cara sendiri dalam beternak babi. Cara beternak babi dalam masyarakat sarereiket ini yang menjadi acuan bagi individu dalam melakukan ternak babi. Ada beragam proses yang harus dilalui oleh peternak babi ini.

Beternak babi tidak sama seperti beternak sapi, ayam, dan bahkan tidak sama dengan cara beternak babi di luar daerah Mentawai. Ada proses yang harus dijalani dan adabanyak gaut (mantra) dan kekei (pantangan) dalam peternakan babi ini. Tidak adanya gaut (mantra), ataupun pelanggaran atas kekei (pantangan) yang sudah ditentukan akan berakibat pada kegagalan peternakan babi tersebut.

Menurut kepercayaan masyarakat sarereiket pelanggaran kekei (pantangan) dan tidak ada atau tidak bagusnya gaut (mantra), akan berakibat paada kegagalan peternakan. Ternak babi gagal karena babi dimangsa oleh musuh alamiahnya yakni ular saba, ${ }^{3}$. Kemudian gagal karena adanya kematian babi secara masa yang menurut kepercayaan masyarakat disebakan karena sesuatu yang bernaama oiluk. ${ }^{4}$ Kemudian bisa juga babi yang dilepaskan dari kandang tidak pulang lagi kekandang dan pergi entah kemana.

Babi yang diternakan bukanlah babi hutan namun adalah babi yang memang biasa untuk diternakan. Tidak adanya diternakan babi hutan disebabkan karena babi hutan ini tidak bisa dijinakkan. Babi hutan biasanya hanya di buru, kalau dapat langsung disembelih, tidak untuk dibudidayakan.

\section{SILAK : LOKASI PETERNAKAN BABI}

okasi peternakan babi terpisah dengan lokasi pemukiman penduduk. Sebuah sungai besar (sungai Rereiket)

\footnotetext{
${ }^{3}$ Saba adalah nama lokar untuk ular jenis phyton.

4 Penyebab kematian ternak yang menurut kepercayaan masyarakat disebabkan oleh sesuatu yang berbau mistis. Di Sakuddei (schefold, 1991; 63), sekian tahun sekali sebagian besar ternak babi mati akibat wabah penyakit. Wabah penyakit. Wabah penyakit ini lah yang dikenal oleh masyarakat sarereiket dengan istilah oiluk.
}

memisahkan antara lokasi pemukiman penduduk dengan lokasi peternakan babi. Sungai Rereiket berada disebelah timur desa, mengalir dari utara ke selatan. Tempat peternakan babi ini disebut juga dengan istilah "silak atau disilak" yang berarti di seberang.

Silak, lokasi peternakan babi ini banyak terdapat pondok yang disebut oleh masyarakat dengan istlah "sapou sainak". Pondok-pondok (sapou sainak) digunakan sebagai tempat istirahat orang-orang atau pemilik peternakan. Di sekitar pondok (sapou) ini (halaman depannya) biasanya peternak memberi makan babi mereka.

Selain sapou sainak di lokasi ini juga banyak terdapat pohon sagu. Daerahnya yang banyak terdapat rawa membuat para sagu tumbuh subur. Sagu yag melimpah ini menjadi stok untuk pakan babi. Sagu yang digunakan untuk makan ternak ini disebut dengan istilah "surappik".

Selain rawa, kawasan ini juga memiliki daerah yang kering. Daerah yang kering ini banyak ditumbuhi oleh pohonpohon seperti; durian, langsat, manggis, ambacang dll. Selain itu ada juga daerah yang hanya ditumbuhi oleh semak-semak.

Ada beberapa sungai kecil yang mengalir di dalam kawasan ini. Sungaisungai kecil ini nantinya akan bermuara ke sungai besar, yakni sungai Rereiket. Jika musim hujan sungai-sungai kecil ini bisa meluap dan menggenangi daerah sekitarnya.

Banyak terdapat jalan setapak yang membelah-belah kawasan ini. Ada jalan setapak yang menuju daerah lain, seperti ke daerah Rorogot, ke Silak Oianan dll. Ada juga jalan setapak yang menuju sapou babi, jaln seperti ini yang sangat banyak dan kadang tidak terlalu jelas.

Babi yang dipelihara tidak dikandangkan. Babi-babi ini lepas begitu saja, mereka bebas bermain kemanapun mereka inginkan. Babi hanya dikandangkan pada saat atau pada masa penjinakan, yakni selama 1-3 minggu, setelah itu babi dilepaskan. Hal ini membuat babi sangat mudah ditemukan di daerah ini. Anda bisa menemukan babi sesaat setelah menyebrang sungai Rereiket. Bahkan anda bisa melihat babi berkeliaran dari sebrang sungai.

Babi-babi milik para peternak hanya pulang pada saat dipanggil oleh pemiliknya, 
yang juga berarti pemberian makan babi. Peternak babi memanggil babinya dengan cara memukul sebuah loloklok ${ }^{5}$ yang berada di pondok atau sapou sainak nya. Babi miliknya yang mendengar suara loloklok ini akan pulang ke sapou pemiliknya. Hebatnya cara ini, babi yang bukan miliknya (babi orag lain) tidak akan datang meski babi tersebut juga mendengar suara dari loloklok tersebut. Begitupun sebaliknya, babi miliknya tidak akan datang jika mendengar suara loloklok dari sapou sainak orang lain (tetangga).

Setelah selesai makan, babi-babi tersebut akan kembali pergi entah kemana. Pemiliknya pun pulang setelah babi selesai memberi makan para babi miliknya. Bahkan pemilik babi pulang sebelum babi-babi itu selesai makan.

\section{PROSES PETERNAKAN BABI}

A da beberapa roses yang harus dilakukan atau dilalui oleh seorang peternak babi yang memulai dari awal. Memulai dari awal ini maksudnya seorang peternak yang baru memulai peternakan babi, artinya dia memulai dari nol. Proses yang harus dilalui tersebut yakni mulai dari pembuatan sapou sainak (pondok), kemudian pasiuggu, pasibukak, dan sipubalut.

\section{A. Sapou Sainak (Pondok)}

Dari semua proses yang dilakukan oleh seorang peternak babi, yang pertama kali dilakukan adalah membuat sapou sainak (pondok). Sapou sainak (pondok) dibuat berbentuk panggung yang mana bagian bawahnya nanti akan digunakan sebagai tempat penjinakan babi. Bagian atas sapou berbahan kayu dengan atapnya dari rumbia. Sedangkan bagian bawah (tempat penjinakan babi) di pagari dengan menggunakan bambu.

Sapou sainak ini nantinya akan diperlukan oleh peternak babi sebagai tempat tinggal. Selama proses awal peternakan, mulai dari pasiuggu sampai pasibukak. Pemilik babi akan menginap di sapou babi bersama dengan babi

\footnotetext{
${ }^{5}$ Loloklok merupakan sebuah pentongan, ada yang terbuat dari bambu dan ada yang terbuat dari kayu. Bambu atau kayu ini di lubangi bagian tengahnya sehingga jika dipukul menghasilkan bunyi yang lantang atau nyaring.
}

peliharaannya yang berada di bagian bawah sapou. Hal bertujuan untuk mempermudah penjinakan babi, membiasakan babi dengan pemiliknya.

Lokasi mendirikan sapou sainak (pondok) tidak sembarang, ada kriteria khusus untuk pemilihan lokasi tempat mendirikan sapou sainak ini. Lokasi yang dipilih ada lokasi yang disekitarnya banyak terdapat sahu. Kemudian yang menjadi pertimbangan adalah air, lokasi sapou harus dekat dengan sumber air.

Sagu merupakan makanan pokok yang diberikan oleh peternak untuk pakan ternak babinya. Hal ini menyebabkan lokasi tempat mendirikan sapou sainak ini dipilih tempat yang banyak sagu supaya mempermudah pemilik ternak untuk mengambil sagu untuk pakan ternak. Sumber air, selain untuk tempat minum babi bisa juga untuk keperluan si pemilik ternak.

Menurut kepercayaan masyarakat lokasi sapou sainak menentukan atau ikut menentukan perkembangan babi yang diternakan. Jika babi kurus-kurus dan perkembang biakannya lambat (bahkan tidak ada perkembangan) maka bisa jadi lokasi tersebut tidak cocok, sebaliknya jika perkembangan babi bagus maka berarti lokasi tersebut cocok. Jika sebuah lokasi dianggap tidak cocok maka pemilik babi biasanya akan pindah dan membuat sapou saianak yang baru.

Para peternak babi biasanya mendirikan sapou sainak diatas tanah ulayat sukunya. Meskipun ada, namun sangat jarang orang mendirikan sapou sainak di tempat yang bukan merupakan tanah ulayat suku nya. Orang yang mendirikan sapou sainak diatas tanah ulayat orang lain harus meminta izin terlebih dahulu kepada si pemilik tanah.

\section{B. Pasiuggu Sainak}

Pasiuggu sainak bisa diartikan sebagai proses penjinakan babi. Proses ini dilakukan setelah sapou sainak selesai dan sudah dipestakan. Pada tahap ini peternak mengambil babi yang akan diternakan untuk selanjutnya dimasukkan kedalam kandang.

Peternak bisa mendapatkan babi barunya dengan cara membeli kepada orang lain, atau bisa juga didapat dari pemberian orang tuanya. Pasiuggu sainak (Penjinakan) dilakukan dengan cara memasukkan dan mengurung babi kedalam kandang selama beberapa minggu. Babi 
baru akan tetap didalam kandang selama beberapa minggu.

Babi ini dikandangkan (masa penjinakan) selama satu sampai tiga minggu. Lama babi dikandangkan ini tergantung dari babi yang dipelihara. Jika babi tersebut cepat jinaknya (relatif jinak) maka babi hanya akan dikandangkan selama satu minggu, setelah itu bisa dilepaskan. Sementara itu jika babinya agak susah dijinakan (relatif liar) maka bisa memakan waktu sampai 3 minggu untuk bisa melepaskan babi terebut.

Babi yang sudah jinak itu tandanya dia agak manja. Jika diletakkan makanan di atas lantai sapou sainak (pondok), maka babi yang berada dibagian bawah sapou sainak akan bersuara, terkesan meminta makan. Menurut orang "sarereiket", babi itu menangis atau terkesan menangis. Nah, jika begitu sifat babi maka berarti dia sudah jinak dan sudah bisa dilepaskan. Jika dilepaskan dia akan pulang kembali kekandang jika dipanggil dengan loloklok.

Babi yang belum jinak, tandanya jika diberikan makan atau diletakkan makanan diatas lantai sapou sainak babi tersebut tidak merespon. Bisa dikatakan dia tidak mau diberi makan. bahkan dia melawan jika dikasih makan oleh pemiliknya. Di dalam kandang, babi yang masih belum jinak, selalu berada di sudut kandang atau selalu menyudut. babi yang seperti ini berarti belum bisa dilepaskan. Jika dilepaskan dia tidak akan pulang ke sapou sainak pemiliknya meskipun dipanggil dengan cara memukul loloklok.

Sejak babi dimasukkan ke kandang hingga babi siap untuk dilepaskan, pemiliknya selalu memukul loloklok. Tujuannya adalah supaya babi yang dikandangkan bisa mengenal suara dari loloklok pemiliknya. Sehinga saat dilepaskan nanti dia tidak akan datang jika mendengar suara loloklok yang bukan dari sapou pemiliknya.

\section{Pasibukak}

Pasibukak merupakan suatu tahap mengeluarkan babi dari kandangnya, bisa juga berarti melepaskan babi dari kandangnya. Hal ini dilakukan setelah babi tersebut telah jinak. Setelah babi dilepaskan maka babi tidak akan dikandangkan lagi, dia akan bebas bermain kemanapun.

Pasibukak ini dilakukan di waktu sore hari, sekitar pukul 18:00. Tujuannya adalah agar babi yang baru dilepaskan tidak pergi terlalu jauh. Sehingga esok pagi saat dipanggil, babi tersebut bisa langsung pulang. Hal ini dilakukan untuk mengurangi resiko babi hilang karena pergi terlalu jauh, maklum kan baru dilepas.

Jika peternak tidak menjalani kekei dan gautnya tidak baik, maka pada saat pelepasan ini babinya tidak lagi pulang kekandang. Babi tersebut lari kehutan dan tidak pulang-pulang lagi kepada pemiliknya. Jika peternak sedang beruntung, beberap lama kemudian akan ada yang melaporkan bahwa dia melihat babi nya yang hilang di suatu tempat, namun hal ini sangat jarang terjadi.

Selama proses pasiuggu sampai pasibukak selesai orang lain tidak boleh masuk atau bertamu ke sapou sainak yang sedang melakukan proses pasiuggu ini. Supaya orang lain tau bahwa dia sedang melakukan pasiuggu sainak maka dipasang lah kekrei ${ }^{6}$. Orang yang melihat kekrei akan langsung mengerti dan tidak akan masuk atau mendatangi sapou sainak tersebut.

Dalam proses melakukan peternakan babi tersebut ada kekei yang tidak boleh dilanggar. Selain kekei (pantangan)ada juga gaut (ramuan yang dimantrai) yang dipercaya bisa membuat babi aman dari serangan predator alaminya yakni ular phyton (ulou saba), aman dari roh hutan, dan menjamin babi berkembang dengan baik. Pelanggaran atas kekei dan tidak adanya gaut akan berujung pada kegagalan peternakan babi.

Ada juga peternak babi di sarereiketyang tidak melalui proses tersebut diatas. Dalam hal ini mereka hanya melanjutkan apa yang sudah dimulai oleh orang tua nya. Orang tua nya yang memulai peternakan dari awal sampai selesai (mulai dari membuat sapou, pasiuggu, sampai pasibukak). Termasuk kekei dan gautnya juga orang tuanya yang menjalani. Setelah babinya jinak dan sudah dilepaskan, barulah anaknya masuk untuk melanjutkan. Dengan demikian juga berarti peternakan tersebut merupakan milik si anak.

\footnotetext{
${ }^{6}$ Kekere terbuat dari daun pohon nibung. Kekre dipasang dengan cara memancangkannya ditanah tepat di persimpangan jalan setapak masuk ke sapoou sainak. Bagian dalam daun menghadap ke arah sapou sainak.
} 


\section{Sipubalut}

Saat babi dilepaskan dari kandangnya (pasibukak), esok harinya peternak memanggil dan memberi makan babi. Makan pertama ini bukanlah sagu, melainkan sesuatu yang dianggap spesial. Makanan yang spesial ini berupa udang dan ikan yang dicari disungai oleh istri peternak. Ini lah yag dinamakan Sipubalut.

Ada juga peternak yang melakukan sipubalut di pagi hari sebelum babi dilepaskan. Karena itu sipubalut bisa juga diartikan pemberian bekal atau persiapan. Bekal untuk si babi yang sudah dilepaskan dan tidak dikandangkan lagi.

\section{KEKEI : PANTANGAN PETERNAK BABI}

K ekei merupakan pantangan atau larangan, dalam hal ini berarti pantangan atau larangan yang harus dipatuhi oleh peternak babi. Kekei ini dilakukan pada waktu-waktu tertentu. Kekei dilakukan atau wajib dikerjakan diwaktu proses penangkaran atau penjinakan babi dan disaat babi hamil tua (pergi melahirkan).

Dalam keyakinan masyarakat, seorang peternak babi yang sedang melakukan pasiuggu sainak (penangkaran babi) harus lah menjalani kekei. Kekei akan berakhir setelah babi dilepaskan dari kandang (setelah pasibukak selesai dilakukak). Sukses atau tidaknya peternakan babi di hari depan ditentukan oleh keki yang dijalani. Jika pemilik babi tidak melaksanakan kekei (mulai dari saat pasiuggu sainak hingga selesai pasibukak) maka peternakan tersebut akan gagal. Sebaliknya jika kekei dilaksanakan dengan baik maka peternakan babi akan berhasil.

Beragam bentuk kegagalan bisa terjadi dalam peternakan babi karena tidak dipatuhi atau tidak dilaksanakannya kekei oleh peternak. Bisa saja setelah dilepaskan babi milik peternak yang tidak melaksanakan kekei tersebut mati dimakan oleh saba (sejenis ular phyton). Ada juga yang babinya tidak mau berkembang biak, kemudian setelah lama babi induknya mati begitu saja. Kemudian bisa saja pada saat dilepaskan (selesai pasibukak) babi pergi jauh kedalam hutan dan tidak kembali lagi ke sapou sainak.

Ada banyak pantangan atau kekei yang harus dijalani dan tidak dilanggar selama proses pasiuggu sainak hingga proses pasibukak, diantaranya adalah:

1. Tidak boleh berhubungan badan.

2. Tidak melakukan kegiatan yang berat (seperti menebang kayu, merambah semak, menanam, membuat rumah, dII)

3. Tidak boleh menyisir rambut.

4. Tidak boleh makan lojo(ikan panjang)

5. Tidak boleh makan shokcak (tupai)

6. Tidak boleh menangkap ikan.

Kekei di atas sama dengan kekei yang di harus dilakukan oleh seorang suami ketika istrinya hamil. Dari sini bisa terlihat bahwa betapa pentingnya ternak babi ini. Peternak babi menjalani kekei ini dengan baik, sehingga menimbulkan kesan sayang.

Selain pada saat pasiuggu sainak pemilik babi juga harus menjalani kekei pada saat babi mereka pergi untuk melahirkan. Babi yang melahirkan tidak akan pulang ke sapou sainak selama kurang lebih satu minggu. Hal ini diketahui oleh pemilik saat dia pergi ke sapou sinak untuk memberi makan babi. Jika babi yang tadinya hamil sudah tidak ada atau tidak datang maka berarti babi tersebut pergi untuk melahirkan.

Babi tidak melahirkan di sekitar sapou sainak. Saat babi hamil akan melahirkan dia pergi kesuatu tempat (semak-semak di dalam hutan) untuk membuat sarang tempat melahirkan. Tempat babi melahirkan ini cukup jauh dari sapou sainak, bahkan biasanya pemilik babi tidak tau dimana babinya melahirkan. Setelah melahirkan dan anaknya sudah cukup kuat barulah si babi pulang ke sapou sainak.

Pemilik babi menjalani kekei sejak dia mengetahui bahwa babinya yang hamil tidak pulang dan pergi ke semak-semak untuk melahirkan. Kekei yang harus dijalani sama dengan kekei yang dijalani pada saat proses pasiuggu sainak. Kekei ini berakhir saat peternak sudah melihat babi tersebut pulang kekandangnya.

Saat pertama kali meliat babi yang pergi untuk melahirkan ini pulang, ada pula semacam prosesi kecil-kecilan yang harus dilakukan oleh sipemilik babi. Pemilik babi akan mengambil segenggam abu dari tungku yang ada di sapou sainak, kemudian di bubuhkan ketubuh induk babi dan anak- 
anak nya yang baru lahir. Pembacaan mantra mengiringi pembubuhan dengan debu tersebut. Inti dari mantra tersebut yakni agar anak-anak babi yang baru lahir bisa aman dari ular phyton (ulou saba), aman dari roh hutan, dan berkembang dengan baik.

\section{GAUT : RAMUAN DAN MANTRA PETERNAK BABI}

$\sim$ ra aut merupakan perpaduan antara ramuan dan mantra, bisa dikatakan gaut merupakan ramuan yang di mantrai. Ramuan terdiri dari beberapa helai daun dari beberapa tumbuhan yang berbeda. Sedangkan mantra merupakan perkataan yang diucapkan secara lisan.

Delfi $(2012$; 8) menuliskan bahwa gaut itu merupakan perantara. Gaut sebagai perantara digunakan untuk mempengaruhi roh-roh yang ada, perantara ini adalah tumbuhan. Ada perantara baik (simaeru) dan ada perantara buruk (sikataik), perantara baik untuk mencapai suatu yang diinginkan atau diharapkan. Sementara itu perantara buruk adalah untuk menghindari segala yang tidak diharapkan sesuatu yang jahat dan merusak.

Sama halnya dengan kekei, masyarakat Mentawai juga mempercayai bahwa perkembangan peternakan babi juga ditentukan oleh gaut yang di pakai oleh peternak. Jika gautnya pas, katakanlah bagus, maka peternakan babi akan sukses, babi akan berkembang biak dengan baik dan cepat. Sebaliknya jika gautnya tidak bagus atau kurang bagus maka peternakan babi itu akan mengalami kegagalan.

Gaut juga menentukan cepat atau lambatnya proses penjinakan (pasiuggu) babi. Peternak yang memiliki gaut yang bagus atau hebat, bai yang dikandangkan akan cepat jinaknya. Satu minggu saja dikandangkan babi tersebut sudah bisa dilepaskan. Sebaliiknya jika gautnya tidak bagus maka peroses penjinakan akan lebih lama, bisa sampai 3 mingu baru babi bisa dilepaskan.

Ada perbedaan gaut antara satu peternak dengan peternak lainnya, dalam hal ini tidak menutup adanya kemungkinan kesamaan gaut mereka. Gaut yang digunakan oleh peternak "A" bisa saja sama dengan peternak " $B$ ", namun belum tentu sama dengan gautnya peternak "C". Hal ini terjadi karena tingginya tingkat kerahasiaan dari gaut ini.

Mereka (peternak babi) yang satu suku kemungkinan besar memiliki gaut yang sama. Paling tidak mereka yang satu bapak akan memiliki gaut yang sama. $\mathrm{Hal}$ disebabkan karena mereka satu keturunan yang sama.

Dua orang peternak dari suku yang berbeda juga ada kemungkinan sama gaut nya. Hal ini disebabkan karena adanya proses jual beli. Dengan kata lain, gaut bisa diperjual belikan kepada orang lain.

Jual beli gaut ini tidak menggunakan uang, namun dengan menggunakan benda atau barang. Bisa dikatakan semacam barter. Seseorang bisa membeli gaut dengan menggunakan pohon durian, sagu, babi, kuali, gong,dll. Untuk harga tukar suatu gaut tergantung dari kesepakatan pembeli dan penjual. Bisa saja kesepakatannya si pembeli harus membayar kepada sipemilik gaut dengan dua batang durian dan sebuah gong, atau bisa saja dengan 10 ekor babi jantan yang besar.

Gaut mulai dipasang atau digunakan saat babi pertama kali dimasukkan kedalam kandang untuk penjinakan (pasiuggu sainak). Gaut (dedaunan yang sudah dimantrai) tersebut ditanam di dalam tanah kandang babi. Kemudian saat babi akan dikeluarkan dari kandangnya (pasibukak). Pada saat ini gaut ditanam (ada juga yang bilang diletakkan begitu saja) di tanah tepat dibawah pintu kandang tempat keluar babi. Setelah itu esok harinya saat babi pertama kali pulang ke sapou sainak setelah ia dilepas (pasibukak).

Gaut terdiri dari berbagai macam dedaunan. Dari beragam jenis gaun yang dihunakan, masing-masing daun memiliki fungsi sendiri-sendiri. Masing-masing daun juga dimantrai dengan ucapan yang berbeda-beda (tergantung jenis daun). Ada daun yang dipercaya berguna untuk melindungi babi dari terkaman saba ${ }^{7}$. Ada pula daun yang dipercaya bisa membuat babi berkembang dengan baik. Kemudian ada juga daun yang dipercaya bisa melindungi babi dari roh hutan. Tentunya daun-daun tersebut akan berfungsi setelah di mantrai.

Masyarakat sarereiket percaya ada kekuatan diluar dirinya yang yang sangat

\footnotetext{
${ }^{7}$ Ular phyton ang merupakan predator alami babi
} 
mempengaruhi atau yang menentukan keberhasilan peternakan mereka. Mereka mencoba berdamai dengan kekuatan yang berada diluar mereka tersebut. Cara perdamaian yang dilakukan adalah melaui media "gaut".

\section{SURAPPIK : PAKAN TERNAK BABI}

$\mathrm{P}$ eternak babi di sarereiket memberi pakan ternak babi nya dengan sagu. Untuk yang satu ini, sagu lebih banyak dihabiskan oleh babi dari pada dikonsumsi oleh manusia. Sagu untuk pakan ternak ini di sebut "surappik".

Pemberian surappik untuk pakan tidak menentu atau tidak ada ketentuan khusus. Semuanya tergantung dari si pemilik peternakan. Ada peternak yang memberi makan babi nya rutin satu kali sehari (pagi hari atau hanya sore hari), ada juga peternak yang memberi makan ternak babinya rutin dua kali sehari (pagi dan sore). Ada juga yang memberi makan babinya 3 kali dalam satu minggu, bahkan ada juga yang hanya satu kali satu minggu.

Adanya perbedaan ini dikarenakan perbedaan sifat dan pemikiran si pemilik ternak. Ada peternak yang berfikir babi tidak akan mati kelaparan walaupun tidak di beri makan, maka dia agak jarang ke sapou sainak untuk memberi makan. Peternak yang lain memeberi makan babinya setiap hari dan berharap agar babinya cepat besar dan cepat pula berkembang.

Intensitas pemberian makanan tentu juga memberi pengaruh kepada babi peliharaan. Babi yang diberi makan setiap hari tentunya akan lebih gemuk dibandinkan babi yang diberi makan hanya satu kali satu minggu. Selain itu, babi yang diberi makan setiap hari relatif akan lebih jinak dibandingkan dengan babi yang hanya diberi makan satu kali dalam satu minggu.

Sagu yang ditumbang untuk dijadikan pakan babi (surappik) adalah sagu yang sudah berbuah yang berarti sudah berisi tepung sagu. Kemudian batang sagu yang sudah ditumbang dipotong-potong, satu batang sagu bisa menghasilkan 5 sampai 8 potongan (tergantung dari tingginya batang sagu yang dipotong). Satu potongan sagu ini disebut dengan istilah "tual', satu "tual" panjangnya kurang lebih $65 \mathrm{~cm}$.

Potongan sagu (tual) ini yang nantinya akan diberikan untuk pakan babi. Sebelum diberikan untuk makan babi,"setual surappik"(satu potong sagu untuk makan babi) ini di belah menjadi 4 bagian. Tujuannya adalah untuk mempermudah babi memakan sagu tersebut, kemudian juga untuk mempermudah pembagian pakan babi.

Babi diberi makan dengan cara melemparkan begitu saja potonganpotongan sagu. Potongan sagu dilempar ketanah di sekitar halaman sapou sainak, sementara itu si pemilik tetap berada di atas sapou sainak. Di tanah sekitar sapou sainak inilah babi-babi menikmati sagu pemberian pemiliknya.

Lebih banyak sagu yang dikonsumsi oleh babi dibanding sagu yang di konsumsi manusia. Satu batang sagu (8 tual) bisa dihabiskan dalam waktu 2 minggu untuk 5 ekor babi. Sementara jika untuk makan manusia satu batang tersebut bisa tahan kurang lebih selama 4 bulan, untuk konsumsi 5 orang anggota keluarga.

5 ekor babi bisa menghabiskan satu batang sagu selama 2 minggu. Bisa di bayangkan berapa batang sagu yang harus disediakan peternak jika dia memiliki puluhan bahkan ratusan ekor babi. Orangorang yang memiliki banyak babi (puluhan hingga ratusan ekor) terkadang harus menyediakan satu batang sagu setiap harinya untuk makan babi. Schefold (1991; 62) menuliskan bahwa orang Sakuddei setiap harinya membutuhkan satu batang sagu untuk makanan babinya.

\section{FUNGSI BABI}

- ungsi babi dalam masyarakat sarereiket adalah untuk konsumsi dalam pesta adat (punen), mahar atau maskawin (alak toga), digunakan dalam prosesi pengobatan yang dilakukan oleh sikerei, dan untuk pembayaran denda adat (tulou). Selain itu saat ini babi juga bisa dijual, dengan kata lain babi saat ini bisa menghasilkan rupiah.

Tidak ada pesta adat (punen) yang tidak menggunakan daging babi sebagai makanan atau hidangan pesta (punen). Masyarakat sangat menyukai daging babi ini. Bagi mereka daging babi merupakan santapan yang lezat dalam semua pesta adat (punen)

Selain untuk di konsumsi, babi juga berfungsi sebagai pembayaran mahar atau 
maskawin. Mahar atau maskawin yang harus dibayarkan oleh pihak keluarga mempelai pria kepada pihak keluarga mempelai wanita. Mas kawin ini dalam masyarakat sarereiket disebut dengan istilah "alak toga", yang secara harfiah berarti "menjemput anak".

Dalam prosesi pengobatan babi bisa berfungsi sebagai upah untuk sikerei yang melakukan pengobatan. Berbeda dengan maskawin (alak toga) babi yang diberikan kepada sikerei bukanlah babi hidup, melainkan babi yang sudah di sembelih dan di potong-potong dagingnya. Daging babi tersebut dimasak dimakan bersam-sama, diluar makan sudah dikeluarkan jatah untuk sikerei yang melakukan pengobatan. Jadi selain jatah untuk makan bersama, sikerei yang melakukan pengobatan juga mendapat jatah daging babi untuk di bawa pulang. Jatah untuk makan bersama di bawa pulang ini lah yang saya sebut sebagai upah.

Kebanyakan orang menyebut daging jatah untuk sikerei itu sebagai ucapan trimakasih. Di sisi lain itu bisa dilihat sebagai upah atas jasa yang telah dilakukan oleh sikerei tersebut. Hal yang wajar jika seorang sikerei mendapat upah atas jasa yang telah dia berikan.

Hewan ternak babi ini bisa juga digunakan sebagai alat pembayaran denda adat (tulou). Tulou atau denda adat adalah hukuman berupa pembayaran yang harus di bayarkan oleh pihak yang dinyatakan bersalah kepada pihak tertentu. Pembayaran tulou ini tidak hanya dengan menggunakan babi, namun bisa juga dengan pohon durian, kuali besar, gong, dll.

Meskipun kebanyakan babi dipotong hanya pada saat ada pesta (punen), namun bukan berarti tidak boleh memotong babi dan menkonsumsinya di luar pesta (punen). Babi dari peternakan ini juga boleh di potong untuk konsumsi sehari-hari. Tidak ada larangan dan ketentuan khusus jika sipemilik babi ingin menyembelih babinya untuk dikonsumsi oleh keluarganya di luar upacara adat (punen).

Selain untuk konsumsi dalam pesta adat (punen), babi sangat jarang atau bisa dikatakan tidak digunakan untuk memenuhi kebutuhan konsumsi sehari-hari. Delfi $(2012 ; 3)$ mengatakan bahwa untuk memenuhi kebutuhan sehari-hari akan daging (protein), masyarakat Mentawai memilih untuk memburu binatang hutan seperti; tupai (tupaia chrysogaster), trenggiling (Manis Javanica), kelelawar (Cynoterus Brachyotis), rusa (Servus Unicolor), dan beberap jenis primata. Namun hal yang paling sering dilakukan untuk memenuhi kebutuha aka daging (protein)adalah mencari ikan ke sungai (yang dikerjakan oleh kaum wanita), mencari ulat sagu (tamra), dan membeli ikan yang di bawa oleh pedagang dari Muara Siberut. Terkadang mereka juga berburu babi hutan (sus srofa), untuk memenuhi kebutuhan protein.

Seorang pemilik babi yang memotong babi untuk dikonsumsi, bukan berarti babi itu hanya dimakan oleh keluarga intinya saja. Babi yang disembilih akan dimasak dan di bagi-bagikan daginggnya kepada keluarga luasnya (satu suku).

Saat ini babi juga bisa di jual. Harga perkilogramnya adalah Rp.30.00. Babi-babi ini dijual kepada penampung di sekitar kawasan Muara (Puro, Munte, dan Muara Siberut). Jika penampung tersebut yang menjemput ke desa maka dia bisa membeli dengan harga Rp.20.000/Kg.

\section{KESIMPULAN}

$\mathrm{B}$ abi pulang karena mendengar suara dari loloklok pemiliknya, menurut orang sarereiket (para peternak), babi tersebut pulang karena menganggap bapaknya datang untuk memberi makan. Pemikiran orang sarereiket ini mengibaratkan pemilik babi adalah sebagai bapak dari babi yang ternakkannya.

Kekei yang dijalani oleh sipeternak babi saat pasiuggu sampai selesai pasibukak sama dengan kekei yang harus dijalaninya saat sang istri hamil. Bahkan saat babi hamil tua dan pergi untuk melahirkan, pemilik babi akan menjalani kekei yang sama juga dengan kekei yang harus dijalaninya saat sang istri hamil. Dari sini terlihat arti penting babi bagi masyarakat rereiket.

Hingga masa ini, babi masih sangat diperlukan dalam kehidupan masyarakat sarereiket. Babi selalu ada dalam punen, babi bisa sebagai alat untuk pembayaran denda adat (tulou), babi digunakan sebagai mahar (alak toga, babi juga digunakan dalam pengobatan yang dilakukan oleh sikerei, dan babi juga bisa di jual.Pentingnya babi dalam kehidupan masyarakat membuat 
peternakan babi ini mendapat perhatian khsusus.

Ada banyak pantangan (kekel) yang harus diperhatikan oleh pemilik babi. Ada gaut yang harus dikerjakan dengan hati-hati oleh sipemilik babi. Pemilihan lokasi sapou yang baik untuk perkembangan babi juga menjadi pertimbangan pemilik babi. Pemberian Pakan babi yang membuat peternak harus rajin menumbang, memotong dan membelah pohon sagu.

Hal di atas membuat "babi, hewan ternak kesayangan" menjadi pilihan untuk judul tulisan ini!

\section{Daftar Pustaka}

Delfi Maskota. 2012. Sipuisilam Dalam Selimut Arat Sabulungan Penganut Islam Di Mentawai Siberut. Jurnal Al-Ulum Volume. 12, Nomor 1, Juni 2012.

Kasman Syaiful. 2014. Fungsi Muncak Dalam Aktivitas Buru Babi (Studi Kasus; Aktivitas Buru Babi Di Beberapa Daerah Pinggiran Kota Padang). Fakultas IImu Sosial Dan IImu Politik. Universitas Andalas. Padang

Suparlan Parsudi. 2004. Hubungan Antar Suku Bangsa. Yayasan Pengembangan Kajian IImu Kpolisian. Jakarta.

Schefold Reimar. 1991. Mainan Bagi Roh, Kebudayaan Mentawai. Balai Pustaka. Jakarta. 